\title{
Fatal neonatal septicaemia and meningitis due to Haemophilus influenzae acquired from the mother
}

\author{
B. ChatTOPADHYAY \\ M.B.B.S., M.R.C.Path., D.C.P. \\ Public Health Laboratory and Department of Microbiology, \\ Whipps Cross Hospital, London E11 INR
}

\section{Summary}

A fatal case of neonatal Haemophilus influenzae type b, septicaemia and meningitis is described. Although the mother was asymptomatic, maternal genital tract culture yielded $H$. influenzae which was indistinguishable from the strain found in the infant. Despite the rarity of this organism as a cause of neonatal sepsis, increased awareness is essential so that this important offending pathogen is not missed.

KEY WORDS: neonatal, Haemophilus influenzae, septicaemia, meningitis, maternal genital tract.

\section{Introduction}

$H$. influenzae is rarely grown from the female genital tract (Hurley, 1970) and in a recent survey of cervical cultures among normal and pregnant women the isolation rate was less than in $1 \%$ (Khuri-Bulos and McIntosh, 1975). Though a rare cause of neonatal infection, it is one of the commonest pathogens in children under the age of 3 years (Fothergill and Wright, 1933). As most adults possess serum bactericidal antibody against $H$. influenzae, the scarcity of neonatal infections has been attributed to the passive transfer of protective antibody to the baby. Therefore, any well documented rise in incidence of $H$. influenzae type b during the past few years may be attributed to absence or low level of antibody against this pathogen. However, this has not proved to be the case and the age distribution of $H$. influenzae meningitis has not changed during the past four decades (Peter, 1973).

\section{Case report}

A $2780 \mathrm{~g}$ boy was born to a 31-year-old primigravida. Gestational age was estimated to be 37 weeks. Rupture of the membranes occurred $22 \mathrm{hr}$ prior to an assisted breech delivery. At birth the infant had an Apgar score of 4 at $1 \mathrm{~min}$ and 9 at $5 \mathrm{~min}$ and the condition was fair. The only method of resuscitation was to clear the airways by mucus extractor. Fortyeight hours after birth the baby suddenly collapsed and was transferred to the Special Care Baby Unit where he began to have convulsions.

Cerebrospinal fluid (CSF) examination revealed red cells $1.48 \times 10^{9} / 1$ white cells $0.54 \times 10^{9} / 1$ (all polymorphonuclear leucocytes), Gram negative rods +++ , which on culture grew $H$. influenzae type $b$, sensitive to ampicillin and chloramphenicol. CSF protein was $1.65 \mathrm{~g} / 1$ and glucose $1.1 \mathrm{mmol} / 1$. Blood cultures also grew the same organism. No pathogens were isolated from nose, throat, ear, umbilical, rectal swabs, end of endotracheal tube and from pharyngeal suction. The white cell count was $3.3 \times 10^{9} / 1$ and the serum calcium $1.69 \mathrm{mmol} / \mathrm{l}$.

Treatment was started with ampicillin and chloramphenicol (300 mg and $35 \mathrm{mg}$ intravenously 4 times a day respectively) with phenobarbitone and dexamethasone. At this stage throat and high vaginal swabs were collected from the mother were which latter on culture yielded $H$. influenzae. The three isolates of $H$. influenzae - from the CSF and blood of the infant and the vagina of the mother were identified to be type $b$, confirming that the baby acquired it from the mother (Dr D. C. Turk, Public Health Laboratory, Northern General Hospital, Sheffield). Despite ventilation and other supportive measures, in view of the baby's rapidly deteriorating condition with convulsions, cyanosis, grey colour, apnoea and laboured respiration, a second lumbar puncture was performed $72 \mathrm{hr}$ after the first one. This showed Gram negative rods but was sterile on culture. However, his condition deteriorated further with right upper lobe pneumonia, pulmonary haemorrhage, evidence of necrotizing enterocolitis, and severe neurological changes; he died on the 7 th day.

\section{Discussion}

Like Group B streptococcal infection, the pathogenesis of neonatal $H$. influenzae infection appears 
likely to be due to transmission of organisms from mother to baby at or immediately before delivery. That infection can occur before birth is highlighted by the fact that there is a report of septic abortion infected with $\boldsymbol{H}$. influenzae (Berczy, Fernlund and Kamme, 1973), and high incidence of prematurity and bacteraemia in infants with early onset $H$. influenzae sepsis (Lillien et al., 1978). Contrary to what was anticipated, genital carriage rate is very low (White and Koontz, 1968; Khuri-Bulos and McIntosh, 1975). Nevertheless it was invariably present in the genital tract of mothers whose babies developed sepsis (Khuri-Bulos and McIntosh, 1975; Granoff and Nankervis, 1975; Nicholls, Yuille and Mitchell, 1975; Marston and Wald, 1976; Bale and Watkins, 1978). Unfortunately, except those mentioned above, in other reports there was either failure to collect any swabs or to record results of culture reports from mothers. In this particular case the mother was asymptomatic with no vaginal discharge or pyrexia and there was no relevant immediate past history to suggest carriage of such pathogens.

Although this baby was not premature, he succumbed not only because of overwhelming infection due to septicaemia and meningitis, but also because of very low white count, low calcium, and sudden collapse at $72 \mathrm{hr}$ which needed intubation leading to pulmonary haemorrhage terminally. This is only the second report of neonatal $H$. influenzae sepsis in the United Kingdom where the same organism has been demonstrated to be present in the maternal genital tract.

\section{Acknowledgments}

I am grateful to Dr B. Lewis, Consultant Paediatrician, fơ allowing me to publish details of the case and to Dr D. C. Turk for confirmation of my laboratory findings.

\section{References}

BALE, J.F. \& WATKINS, M. (1978) Fulminant neonatal Haemophilue influenzae pneumonia and sepsis. Journal of Pediatrics, 92, 233.气 BerCZY, J., Fernlund, K. \& KAMME, C. (1973) Haemophilus influenzae in septic abortion. Lancet, i, 1197.

FOTHERGILL, L.D. \& WRIGHT, J. (1933) Influenzal meningitis: The relation of age incidence to the bactericidal power of blood against the causal organism. Journal of Immunology, 24, 273.

GRANOFF, D.M. \& NANKERVIS, G.A. (1975) Infectious arthritis i⿱亠凶禸 the neonate caused by Haemophilus influenzae. American Journ of Diseases of Children, 129, 730.

HURLEY, R (1970) Haemophilus endometritis in women fitted wit Lippes Loop. British Medical Journal, 1, 566.

KHURI-BUlOS, N. \& MCINTOSH, K. (1975) Neonatal Haemophilus influenzae infection. American Journal of Diseases of Childreß 129, 57.

LILLIEN, L.D., YEH, T.F., NoVAK, G.M.\& JACOBS, N.M. (1978\ Early-Onset Haemophilus sepsis in newborn infants: clinica, roentgenographic, and pathologic features. Pediatrics, 62, 299. 윽 MARSTON, G.\& WALD, E.R. (1976) Haemophilus influenzae type $\vec{b}$. sepsis in infant and mother. Pediatrics, 58, 863.

Nicholls, S., Yuille, T.D. \& Mitchell, R.G. (1975) Perinata infections caused by Haemophilus influenza. Archives of Disease Childhood, 50, 739.

Peter, G. (1973) Discussion, in Sell SHW, Karzon, D.T. (editors): Haemophilus influenzae. Nashville, Tenn, Vanderbilt Universityo Press, p. 264.

WhITE, C.A.\& KoonTZ, F.P. (1968) Bacterial flora of the cef during pregnancy. Obstetrics and Gynecology, 32, 402.

(Accepted 5 July 1983) 